\title{
Pojęcie podmiotowości w pedagogice
}

Po

ojęcie podmiotowości, genetycznie związane z pojęciem podmiotu - jako coś, co mu przysługuje - stanowi przedmiot zainteresowania filozofii (zwłaszcza antropologii filozoficznej), psychologii, socjologii, nauk prawnych, a także pedagogiki. Przedmiotem artykułu są różne znaczenia terminu „podmiotowość”, które pojawiają się na gruncie pedagogiki w kontekście zagadnień związanych z opieką, szczególnie w sporach dotyczących jej charakteru oraz granic.

Jednym ze sposobów ujawnienia treściowej złożoności terminu „podmiotowość" jest prześledzenie kontekstów, w których się on pojawia. Etymologicznie termin ten wywodzi się od słowa „podmiot”, który, jako odpowiednik greckiego hypokeimenon ${ }^{1}$ i łacińskiego subiectum, pochodzi od czasownika „mieść”, posiadającego dwojakie znaczenie: „rzucania”/,miotania” (łac. iacere) i „zamiatania” ${ }^{2}$. Słowniki języka polskiego wskazują na trzy główne znaczenia terminu „podmiot”: 1. językoznawcze: nadrzędna część zdania oznaczająca osobę, przedmiot, zwierzę, pojęcie, zjawisko, o których coś się w zdaniu orzeka; 2. filozoficzne: podstawa czegoś, ośrodek aktywności, ludzkie »ja«, osoba, byt osobowy przeciwstawiany rzeczy lub przedmiotowi; osoba poznająca, przeżywająca, działająca; również osoba aktywna, uczestnicząca w czymś; 3. prawne: osoba fizyczna lub prawna, do której stosują się pewne przepisy prawne ${ }^{3}$.

W metafizyce utożsamia się pojęcie podmiotu jako nośnika treści, z pojęciem substancji; podmiot to fundament, nośnik własności/akcydensów

\footnotetext{
* Dr Agnieszka Salamucha - Instytut Profilaktyki Społecznej i Resocjalizacji Uniwersytet Warszawski,e-mail: a.salamucha@uw.edu.pl

1 Termin ten u Arystotelesa (Kategorie, 1a20) oznacza to, co nieokreślone, a co stanowi podstawę wszelkich określeń

2 A. Brückner, Słownik etymologiczny języka polskiego, Kraków 1927, za: pl.wikisource.org>wiki>mieść [dostęp 27.06.2018].

${ }^{3}$ sjp.pwn.pl/slowniki/podmiot.html [dostęp 27.06.2018].
} 
(przypadłości), który zachowuje tożsamość bytu . Pojęcie podmiotu (poznania) stanowi, obok aktu poznawczego i przedmiotu poznania, jedno z podstawowych pojęć epistemologii, od czasów Kartezjusza traktowane jako jej punkt wyjścia, które pełni funkcję gwaranta tożsamości i samodzielności bytowej poznającego „ja”. W antropologii filozoficznej pojęcie podmiotu koncentruje się na byciu działającym, sprawcą ${ }^{5}$, przy zaakcentowaniu jego wolności i autonomii. W pedagogice termin „podmiot" ma podobne konotacje jak w antropologii filozoficznej, odnosząc się do statusu człowieka jako bytu obdarzonego poznawczą i moralną autonomią, których podstawowymi konsekwencjami są samoświadomość, sprawstwo i odpowiedzialność za własne czyny $^{6}$. Początek XXI wieku w pewnych nurtach refleksji w humanistyce (m.in. postmodernizm, poststrukturalizm) wiąże się z kryzysem koncepcji podmiotu, przejawiającym się kwestionowaniem jego tożsamości i autonomii oraz spójności ludzkiego doświadczenia, a także pesymizmem dotyczącym ludzkiego poznania i wolności ${ }^{7}$.

„Podmiot” z punktu widzenia prawa oznacza osobę (fizyczną lub prawną) lub w szczególnych przypadkach także jednostkę organizacyjną, która posiada obowiązki bądź uprawnienia wyznaczone przez prawną normę ${ }^{8}$. Z kolei teologiczne pojęcie podmiotu utożsamia go z osobą - najpierw niestworzoną (Bóg Ojciec, Syn Boży, Duch Święty; Trójca Święta) jako przedmiotem namysłu teologicznego w ujęciu scholastycznym, a następnie z osobą stworzoną, zarówno indywidualną (człowiek, anioł), jak i społeczną (Kościół, naród), będącą autorem działań o charakterze rewelatywno-soteryjnym, jednak przy zachowaniu prymatu Boga jako właściwego inicjatora i realizatora tych działań9.

Pojęcie podmiotowości, które pojawia się w naukach humanistyczno-społecznych i prawnych, jest przypisywane jedynie ludziom (jednostkom i grupom społecznym), a nawet stanowi inne określenie człowieczeństwa jako fundamentu dla specyficznie ludzkich cech (albo dyspozycji do tych cech) oraz określonych uprawnień. Z jednej strony akcentuje ono aktywną postawę podmiotu wobec otoczenia, $\mathrm{z}$ drugiej - jest antonimem uprzedmiotowienia (reifikacji). Wśród wyrażeń bliskoznacznych terminu „podmiotowość" wymienia się: tożsamość, samoświadomość, sprawczość, autonomię i indywidualność.

${ }^{4}$ B. Ogrodnik, Podmiot, w: Słownik filozofii, red. J. Hartman, Kraków 2009, s. 169.

${ }^{5}$ M. Lechniak, Podmiot (filozofia), w: Encyklopedia Katolicka, t. XV, Lublin 2011, s. 945-946.

${ }^{6}$ A. Męczkowska, Podmiot, w: Encyklopedia pedagogiczna XXI wieku, t. 4, Warszawa 2005, s. 452-454; por. także W. Okoń, Podmiot, w: tenże, Nowy słownik pedagogiczny, Warszawa 1998, s. 296.

7 A. Męczkowska, Podmiot..., s. 453.

${ }^{8}$ J. Petraniuk, Podmiot (prawo), w: Encyklopedia Katolicka, t. XV, Lublin 2011, s. 948.

9 K. Stola, Podmiot (teologia), w: Encyklopedia Katolicka, t. XV, Lublin 2011, s. 946-947. 
Termin „podmiotowość prawna”, inaczej „osobowość prawna”, określa zdolność podmiotu do uczestniczenia w obrocie prawnym na podstawie obowiązujących norm ${ }^{10}$. W psychologii pojęcie podmiotowości wiąże się z poznawczym podejściem do osobowości, w którym postrzega się człowieka jako integralną całość: podmiot poznający świat i samego siebie, adaptujący się do środowiska, odznaczający się poczuciem autonomii, tożsamości i odrębności od innych ludzi oraz kontroli nad sobą i biegiem zdarzeń ${ }^{11}$. Idea podmiotowości zajmuje szczególne miejsce w badaniach C. S. Rogersa na temat psychologii humanistycznej, stawiającej postulat upodmiotowienia sytuacji badawczej oraz wyrażającej przeświadczenie o istniejącym w każdym człowieku potencjale wewnątrzsterowności, który realizuje się tylko wtedy, gdy występuje brak zewnętrznych blokad wymuszających pewne zachowania ${ }^{12}$. W socjologii pojęcie podmiotowości odnosi się do dyskusji, kto jest sprawcą zmian społecznych (Bóg/siły nadprzyrodzone; organizm/ system społeczny per se; podmioty indywidualne lub kolektywne); pojęcie to zajmuje centralne miejsce $\mathrm{w}$ teorii podmiotowości, przypisującej zmiany i procesy społeczne podmiotowemu sprawstwu jednostek i zbiorowości. Podmiotowość rozumiana jest tu dynamicznie, jako potencjalność realizowana $\mathrm{w}$ aktualnej praktyce społeczno-historycznej ${ }^{13}$.

W pedagogice pojęcie podmiotowości nabiera wyraźnie charakteru wartościującego i sprofilowanego na działalność edukacyjną, pełniąc funkcję hasła promującego cel wychowania jako pełnię osobowej dojrzałości człowieka, szukanie optymalnych warunków uzyskiwania pożądanych efektów oraz ideę podmiotowej roli ucznia w procesie nauczania ${ }^{14}$. Opowiadając się za hasłem podmiotowości, pedagog opowiada się tym samym za określoną koncepcją człowieka: osoby rozumnej i wolnej, kreatora własnego życia (homo faber), którego należy wychowywać poprzez dialog, stymulując jego samorzutny rozwój przy unikaniu środków przymusu. Co więcej, pedagogowi przypisuje się zadanie „upodmiotowienia jednostki w procesie wychowania”, polegające na „pomocy w kreowaniu i wyrażaniu siebie” oraz „wsparciu w zmaganiu się z przeciwnościami tkwiącymi w otoczeniu"15.

${ }^{10}$ J. Petraniuk, Podmiotowość prawna, w: Encyklopedia Katolicka, t. XV, Lublin 2011, s. 949.

${ }^{11}$ Por. M. Kofta, D. Doliński, Poznawcze podejście do osobowości, w: Psychologia. Podręcznik akademicki, t. 2: Psychologia ogólna, red. J. Strelau, Gdańsk 2006, s. 563 i nn.

${ }_{12}$ W. Łukaszewski, Psychologia humanistyczna i jej koncepcja natury ludzkiej, w: Psychologia. Podręcznik akademicki, t. 1: Podstawy psychologii, red. J. Strelau, Gdańsk 2006, s. 77-78.

${ }_{13}$ P. Sztompka, Socjologia, Kraków 2005, s. 448-449; 529-538.

14 A, Męczkowska, Podmiot..., 2005, s. 453; W. Sikorski, Podmiotowość w procesie nauczania, w: Encyklopedia pedagogiczna XXI wieku, t. 4, Warszawa 2005, s. 454-456; J. Sowa, Podmiotowość $w$ wychowaniu, tamże, s. 456-459.

15 J. Sowa, Podmiotowość w wychowaniu..., s. 456. 
Przedstawione konteksty użycia terminu „podmiotowośc” w różnych dziedzinach pokazują jego bogactwo znaczeniowe i pozwalają na zadanie kilku pytań pod adresem jego rozumienia w pedagogice:

1. Jaka jest geneza podmiotowości?

2. jaka jest istota/natura podmiotowości?

3. komu przysługuje podmiotowość?

Pytając o genezę podmiotowości, pytamy de facto o pochodzenie człowieka, rozstrzygając dodatkowo kwestię istnienie Boga i nieśmiertelnej duszy: czy podmiotowość pochodzi od Boga stwórcy, obdarowującego ludzi wyróżnionym statusem ontologicznym, czy też została w jakiś sposób wypracowana samodzielnie przez gatunek ludzki (np. wskutek działania procesu ewolucji). Określenie natury podmiotowości można, zdaniem autorki artykułu, sprowadzić do trzech podstawowych postaci: a) podmiotowości rozumianej jako zdolność/dyspozycja/ potencjalność (w tym pierwotna zdolność stanowiąca fundament dla innych, specyficznie ludzkich), stałej i nieutracalnej; b) aktualizacji tej potencjalności, która ma charakter zmienny i dynamiczny; c) uprawnienia wynikającego z faktu bycia człowiekiem.

Komu przypisuje się podmiotowość? Odpowiedź na to pytanie jest zależna od rozstrzygnięcia, o którą postać podmiotowości chodzi. Podmiotowość jako stała i nieutracalna dyspozycja przysługuje zawsze i wszędzie wszystkim ludziom. Natomiast jej aktualizacja może być zalążkowa (przejściowo, jak w przypadku niemowlęcia, lub trwale, jak u osoby niepełnosprawnej umysłowo w stopniu głębokim), może zostać uniemożliwiona (np. przez ciężką chorobę, starczą demencję lub długotrwałą izolację) albo też przybrać patologiczne formy (casus psycho-, socjo- i charakteropatów), co w niektórych sytuacjach pociąga za sobą ograniczenie albo utratę określonych uprawnień (np. poprzez ubezwłasnowolnienie), wiąże się też ze stopniowym nabywaniem uprawnień (jak w przypadku osoby małoletniej). Kiedy podmiotowość jako aktualizacja nie przybiera swej pełnej formy, pojawia się konieczność opieki.

Autorka pracy proponuje, aby rozpatrywać pojęcie opieki jako dwuczłonową relację $x R y$, gdzie $x$ to podmiot (w znaczeniu przeciwstawienia przedmiotowi) opieki/opiekun, $y$ - przedmiot opieki/podopieczny, a $R$ znaczy tyle co „opiekuje się".

Z punktu widzenia prawa, opiekunem jest osoba powołana do ochrony interesów osobistych i majątkowych innej osoby, jeśli ona tego potrzebuje z powodu małoletniości, braku używania rozumu lub ubezwłasnowolnienia (z reguły funkcję opiekuna pełnią rodzice lub małżonek, albo ustanawia się

${ }^{16}$ Autorka artykułu rozumie relację jako wszelki związek lub zależność zachodzącą między przedmiotami danego (dowolnego) rodzaju (por. B. Stanosz, Relacja, w: Mała Encyklopedia Logiki, Ossolineum 1970, s. 255). 
kuratora $)^{17}$. W pedagogicznych określeniach opiekuna uwaga skoncentrowana jest na pożądanych elementach jego postawy: ma on dawać oparcie (wsparcie), zaspokajać potrzeby, pomagać w zachowaniu fizycznej, psychicznej i duchowej równowagi oraz stymulować rozwój podopiecznego ${ }^{18}$, bezwarunkowo go akceptując (opiekun nie musi aprobować wszystkich poczynań podopiecznego, ale powinien odnosić się do niego z szacunkiem, zaufaniem i wiarą $\mathrm{w}$ jego możliwości samodoskonalenia) ${ }^{19}$. Wyróżnione miejsce w polskiej tradycji opieki społecznej zajmuje kategoria spolegliwego opiekuna Tadeusza Kotarbińskiego, traktowana jako uniwersalny ideał moralny: byłby to człowiek odznaczający się męstwem, dobrocią, prawością, opanowaniem, szlachetnością i bezinteresownością, na którym można zawsze polegać. Podmiot opieki może mieć również charakter zbiorowy (grupa ludzi, organizacja społeczna, instytucja państwowa), rozumiany dystrybutywnie (zbiór jako całość) albo kolektywnie (poszczególne elementy tego zbioru). W kontekście chrześcijańskim może być nim istota nadprzyrodzona - Bóg (pojęcie Opatrzności opiekującej się losami świata i ludzkości) lub anioł stróż (delegowany przez Boga do opieki nad konkretną jednostką).

Przedmiotem opieki/podopiecznym w ujęciu pedagogicznym jest osoba niesamodzielna, która nie osiągnęła jeszcze pełni swojego rozwoju ${ }^{20}$ lub została dotknięta ograniczeniem własnej autonomii w działaniu i rozwoju ${ }^{21}$. Warunkiem koniecznym bycia podopiecznym jest znajdowanie się w sytuacjach, kiedy nieobecność działań opiekuńczych może powodować potencjalne lub rzeczywiste zagrożenie życia i rozwoju podopiecznego ${ }^{22}$. Szeroka formuła dookreślana jest przez wyliczenie tych sytuacji: właściwości organizmu człowieka (dzieciństwo, niepełnosprawność fizyczna i umysłowa, zaburzenia psychiczne, uzależnienia, choroba, starość, sieroctwo naturalne i społeczne, niedojrzałość osobowości); przeszkody rodzinne (zaburzenia struktury i funkcji rodziny); przeszkody szkolne (niepowodzenia szkolne, »drugie życie« szkoły, przemoc i agresja), przeszkody środowiskowe (destrukcyjne grupy rówieśnicze, nieprzystosowanie społeczne, patologia społeczna, zerwanie więzi społecznych) ${ }^{23}$. Milcząco zakłada się tu, że przedmiotem opieki jest zawsze człowiek ${ }^{24}$.

${ }_{17}$ M. Greszata-Telusiewicz, Opiekun (prawo kanoniczne), w: Encyklopedia Katolicka, t. XIV, Lublin 2010, s. 652-653; E. Wilemska, Opiekun (prawo polskie), tamże, s. 653-654; R. Jusiak, Opiekun (pedagogika), tamże, s. 651-652.

${ }_{18}$ R. Jusiak, Opiekun..., s. 651.

${ }_{19}$ M. Łobocki, za: J. Sowa, Podmiotowość $w$ wychowaniu..., s. 456.

20 Tamże.

${ }^{21}$ R. Jusiak, Opiekun..., s. 651.

22 Tamże.

${ }^{23}$ Tamże, s. 651-652.

${ }^{24}$ Niektórzy pedagodzy (Zdzisław Dąbrowski) odróżniają rodzaje opieki ze względu na to, kto jest jej podmiotem i przedmiotem: 1) opiekę w ogóle (gdy podmiot i przedmiot opieki nie musi być 
Relacja opieki jest asymetryczna (zachodząc między elementami $x$ i $y$ danego zbioru, nie zachodzi również między $y$ i $x$ ), nie jest bowiem możliwe przynajmniej w tym samym momencie - aby $x$ opiekował się $y$ i jednocześnie $y$ opiekował się $x$, choć może się zdarzyć, że $x$ i $y$ z czasem zamieniają się rolami (np. rodzic opiekuje się małym dzieckiem, a dorosłe dziecko opiekuje się zniedołężniałym rodzicem). Dyskusyjne jest, czy relacja opieki to relacja przechodnia (zachodząc między elementami $x$ i $y$ oraz $y$ i $z$ z danego zbioru, zachodzi zawsze między $x$ i $z$ ), może się bowiem zdarzyć, że opiekun/kurator osoby $y$ opiekującej się inną osobą $z$, pośrednio sprawuje opiekę również nad $z$. Podobnie, nie jest jasne, czy relacja opieki jest zwrotna (zachodzi między elementem danego zbioru a nim samym), możliwe jest bowiem stwierdzenie, że $x$ opiekuje się sam sobą ${ }^{25}$.

Cel opieki można ująć dwojako: od strony negatywnej, gdy działanie opiekuna dotyczy interwencji w sytuacji zagrożenia lub zaspokajaniu żywotnej potrzeby podopiecznego, oraz od strony pozytywnej, gdy chodzi o pomoc i wsparcie w rozwijaniu przez niego potencjału, osiągnięcie względnej samodzielności i samowystarczalności, umiejętności pokonywania trudności i podejmowania właściwych dla siebie ról społecznych ${ }^{26}$; pomoc w wypracowaniu przez jednostkę, stosownie do jej możliwości, niepowtarzalnej koncepcji życia i jej pełnej realizacji ${ }^{27}$. Koncentrację na negatywnie ujmowanym celu opieki uważa się za podejście tradycyjne albo przestarzałe, natomiast ujmowanie celu opieki w aspekcie pozytywnym traktowane jest jako nowoczesne i zgodne z modelem społeczeństwa obywatelskiego. Środkami działania opiekuna są m.in. świadczenia materialne (rzeczowe), zabiegi organizacyjne (stwarzające warunki prawidłowego rozwoju), pomoc psychologiczna (emocjonalna), wspieranie samowychowania, tworzenie więzi emocjonalnej. Podstawowym kryterium stosowania danego środka winno być dobro podopiecznego ${ }^{28}$.

Pedagogiczna charakterystyka pojęcia opieki jako relacji zdaje się nie uwzględniać odróżnienia między poziomem opisu (quaestio facti) a poziomem normy (quaestio iuris), co widać wyraźnie zarówno przy dookreślaniu pojęcia opiekuna jako altruistycznego, bezinteresownego i afirmującego osobę

\footnotetext{
człowiekiem, a może być zwierzęciem); 2) opiekę ludzką (gdy podmiot to człowiek, a przedmiotem może być inny człowiek, wytwory ludzkie lub elementy świata przyrody); opiekę międzyludzką (gdy podmiotem i przedmiotem opieki są ludzie). Por. M. Winiarski, Opieka pedagogiczna, w: Encyklopedia pedagogiczna XXI wieku, t. 3, Warszawa 2004, s. 855.

${ }^{25}$ Być może wychowanie człowieka do samodzielności polega na tym, żeby potrafił sam wobec siebie sprawować funkcje opiekuńcze.

${ }^{26}$ R. Jusiak, Opiekun..., s. 652.

${ }_{27}$ M. Winiarski, Opieka pedagogiczna..., s. 857.

${ }^{28}$ R. Jusiak, Opiekun..., s. 651.
} 
podopiecznego bez względu na okoliczności, jak i przy pojęciu podopiecznego, traktowanego jako „człowiek bez właściwości”, bez żadnych warunków brzegowych, jeśli chodzi o jego postawę wobec opiekuna. Ponieważ akcent w rozważaniach pada na porządek normatywny (ideał opiekuna i relacji opiekuńczej), brakuje pogłębionej refleksji nad niewłaściwymi postaciami opieki (np. zaniedbanie versus nadopiekuńczość), postawami opiekuna i podopiecznego. Przykładowo, warunkiem koniecznym ze strony podopiecznego jest posłuszeństwo wobec opiekuna - istnieje wówczas niebezpieczeństwo, że opiekun (również w imię dobra podopiecznego) „zagarnie” go dla siebie, albo egoistyczny i roszczeniowo nastawiony podopieczny pod pozorami posłuszeństwa wykorzysta dla swoich celów bezinteresownego opiekuna. Ponadto, pojęcie przedmiotu opieki/podopiecznego zawiera w sobie implicite negatywne konotacje. Historycznie uważano, że istnieją pewne grupy społeczne, które wymagają opieki ze względu np. na swoje zacofanie cywilizacyjne (ludy pierwotne, murzyńscy niewolnicy w Ameryce Północnej) lub słabość intelektualną i moralną (kobiety). Reinterpretacja zjawiska opieki jest obecnie zauważalna przez wprowadzanie definicji projektujących (perswazyjnych): zamiast terminu „opieka społeczna” - „praca socjalna”, zamiast „podopieczny” - „klient”, „beneficjent” itp.

Charakterystyczną, a zarazem kontrowersyjną cechą opieki jest przejęcie przez opiekuna odpowiedzialności za podopiecznego ${ }^{29}$. Czy przejęcie odpowiedzialności za podopiecznego pozbawia go podmiotowości? Zwolennicy odpowiedzi twierdzącej uważają, że odpowiedzialność za własne życie stanowi niezbywalny element podmiotowości, opieka zaś zwalnia człowieka z trudu zmagania się z przeciwnościami życia, realizowania wyznaczonych przez siebie zadań; czyni go zależnym od innych, a przez to depersonalizuje/ odczłowiecza $^{30}$. Ich oponenci wskazują na fakt, że w kluczowych momentach swojego życia bez opieki człowiek nie może przetrwać biologicznie, więc tym bardziej urzeczywistniać swojej podmiotowości, jednak opieka ta winna być tak sprawowana, aby - jeśli to możliwe - podopieczny mógł się jak najszybciej uniezależnić od opiekuna.

Wydaje się, że pomocne w rozstrzygnięciu tej kontrowersji może być odróżnienie trzech znaczeń terminu „podmiotowość”. Podmiotowość jako

${ }^{29}$ Niezwykle bogaty znaczeniowo termin „odpowiedzialność” nie jest przedmiotem niniejszego tekstu, zatem jedynie przykładowo przytoczę jedno z rozumień odpowiedzialności w kontekście relacji „opiekun-podopieczny”: „świadome i dobrowolne spełnianie wszelkich niezbywalnych wymagań życia podopiecznego, czyli ponoszenia wszelkich skutków tego, ŻE SIĘ GO MA, chronieniu, bronieniu i reprezentowaniu jego dobrostanu, decydowaniu za niego, o nim i jego sprawach, a wszystko to na tyle, na ile on sam nie jest zdolny do tego" (Z. Dąbrowski, za: M. Winiarski, Opieka pedagogiczna..., s. 855).

${ }^{30}$ Tamże, s. 856. Skrajne stanowisko w tej kwestii prezentują antypedagodzy (Hubertus von Schoenebeck; por. P. Magier, Esej postpedagogiczny, Lublin 2016). 
fundamentalna, stała i nienaruszalna dyspozycja/potencjalność nie może zostać utracona, ani przez czynniki endogenne (stadium życia, deficyty rozwojowe), ani egzogenne (wpływy środowiskowe, w tym relacja opieki). Zakłócona lub też wsparta przez czynniki wewnętrzne (na gruncie psychiki) lub zewnętrzne (na poziomie funkcjonowania w środowisku) może być natomiast aktualizacja tej potencjalności, przejawiająca się przez - aktualne, a nie potencjalne - używanie rozumu/samoświadomość i wolną wolę. Podmiotowość ujmowana jako aktualizacja potencjalności nie jest człowiekowi dana - realizowanie jej może być przyrównane do przemierzania drogi lub stopniowego budzenia ze stanu uśpienia. Od stopnia aktualizacji zależy, komu i w jaki sposób przysługuje podmiotowość jako uprawnienie. Przyznanie niektórych uprawnień jest nieograniczone (np. prawo do dziedziczenia, które mają również dzieci nienarodzone), inne są ograniczone (z powodu małoletniości, braku używania rozumu, ubezwłasnowolnienia). Idea/pojęcie opieki i opiekuna pojawia się w przypadkach, gdy dana jednostka nie jest podmiotem „do końca” w sensie drugim i trzecim. Na pewnych etapach życia opieka wobec niej jest czymś naturalnym, ale również przejściowym (do momentu zaktualizowania potencjalności); w innych - jeśli wiadomo, że aktualizacja już nie nastąpi - opieka ma charakter stały i ciągły. Mogą również mieć miejsce patologiczne formy opieki: nadopiekuńczość (per excessum) lub zaniedbanie (per defectum), które nie pomagają, ale szkodzą podopiecznemu w rozwijaniu podmiotowości jako aktualizacji potencjalności. Jednak podmiotowość w pierwszym znaczeniu - jako dyspozycja i fundament dla specyficznie ludzkich cech - w każdym przypadku pozostaje nienaruszona.

\section{Bibliografia}

Greszata-Telusiewicz M., Jusiak R., Wilemska E., Opiekun, w: Encyklopedia Katolicka, t. XIV, Lublin 2010, s. 651-654.

Lechniak M., Petraniuk J., Stola K., Podmiot, w: Encyklopedia Katolicka, t. XV, Lublin 2011, s. 945-949.

Męczkowska A., Podmiot, w: Encyklopedia pedagogiczna XXI wieku, t. 4, Warszawa 2005, s. 452-454.

Ogrodnik B., Podmiot, w: Słownik filozofii, red. J. Hartman, Kraków 2009, s. 169.

Petraniuk J., Podmiotowość prawna, w: Encyklopedia Katolicka, t. XV, Lublin 2011, s. 949.

Sowa J., Podmiotowość w wychowaniu, w: Encyklopedia pedagogiczna XXI wieku, t. 4, Warszawa 2005, s. 456-459.

Strelau J., Psychologia. Podręcznik akademicki, Gdańsk 2006.

Sztompka P., Socjologia, Kraków 2005.

Winiarski M., Opieka pedagogiczna, w: Encyklopedia pedagogiczna XXI wieku, t. 3, Warszawa 2004, s. 853-858. 


\section{Streszczenie}

W artykule przedstawiono różne znaczenia terminu „podmiotowość”, które pojawiają się na gruncie pedagogiki w kontekście zagadnień związanych z opieką. Po prześledzeniu kontekstów, w jakich pojawia się ten termin, zaproponowano trzy jego podstawowe rozumienia: 1. specyficznie ludzka, stała i nieutracalna zdolność/dyspozycja/potencjalność; 2. zmienna i dynamiczna aktualizacja tej potencjalności; 3 . uprawnienie wynikające $\mathrm{z}$ faktu bycia człowiekiem. Rozumienia te są przydatne w analizie sporu, czy opieka - rozumiana jako relacja, której charakterystyczną cechą jest przejęcie odpowiedzialności za podopiecznego przez opiekuna - pozbawia podopiecznego podmiotowości.

Słowa kluczowe: Podmiot, podmiotowość, pedagogika, opieka, odpowiedzialność.

\section{The Concept of Subjectivity in Educational Studies}

\section{Summary}

In my paper, I analyze the concept of subjectivity in the context of educational studies, especially polish pedagogy of care and upbringing. I consider three main meanings of the term „subjectivity": 1) typical of human beings, constant ability/disposition/potentiality; 2) changing and dynamic actualization of this potentiality; 3) an authority as a result of being human. These meanings of subjectivity may be useful in the analysis of the dispute, whether the care - as a relation, where a caregiver is responsible for her ward - deprives a ward of her subjectivity.

Keywords: Subject, subjectivity, educational studies, care, responsibility. 